\title{
Role of Plasma Von Willebrand Factor-Antigen in Predicting the Presence of Esophageal Varices and Occurrence of its Bleeding in Cirrhotic Patients: a Cross Sectional Study
}

\author{
Mona A. AbdelMaksoud ${ }^{1}$, Amal A. Jouda ${ }^{1}$, Talaat Fathy ${ }^{1}$, \\ Ahmad Mokhtar Ahmad Ibrahim ${ }^{2}$, Ahmad Sallam Soliman², \\ Ahmad Baraka ${ }^{2}$, Mohammad N. Elkhashab ${ }^{1}$ \\ ${ }^{I}$ Tropical Medicine Department, Faculty of Medicine, Zagazig University,Egypt. \\ ${ }^{2}$ Clinical Pathology Department, faculty of Medicine, Zagazig University, Egypt.
}

Corresponding Author Amal A. Jouda

Mobile: 01016124371

E mail: dr.amaljouda@yahoo. com

Key words: VWF, VITRO score, non-invasive, esophageal varices, marker
Background and study aim: Baveno VI consensus recommended the use of noninvasive predictors of $\mathrm{EV}$ to avoid unnecessary endoscopies. Von Willbrand factor (VWF) and VITRO score, (VWF/ platelet count), are both correlated to liver cirrhosis and fibrosis. The aim of this study was to evaluate the role of VWF and VITRO score as predictors of esophageal varices and their bleeding.

Patients and Methods: Seventy seven patients were included in this study. They were randomly selected from cirrhotic patients admitted to endoscopy unit for the first time. They were allocated into two groups; group I: patients who have esophageal varices, group II: patients with no esophageal varices.

Results: VWF Ag and VITRO score were significantly higher in the varices group

\section{INTRODUCTION}

Portal hypertension is the increase in the portal vein pressure. It occurs as a result of cirrhosis when the change in hepatic architecture leads to increased resistance to the blood flow inside the portal vein tributaries [1,2]. Esophageal varices are dilated blood vessels that appear at the gastroesopahgeal junction as a result of increased portal vein pressure. They occur when the hepatic venous pressure gradient reaches the critical point of $10 \mathrm{mmHg}$ [3]. Patients with portal hypertension develop (group I). VWF Ag level was $169.3 \pm 20.2$ in group I vs $146.8 \pm 35.5 \mu \mathrm{g} / \mathrm{dL}$ in group II $\mathrm{p}<0.001$. VITRO score was $2.2 \pm 1.1$ in group I vs $1.6 \pm 0.7 \mu \mathrm{g} / 10^{8}$ platelet $\mathrm{p}=0.05$. We found that at cut off value of $153 \%$ VWF can predict the presence of EV with sensitivity $88.1 \%$ and specificity of $61.1 \%$ and $\mathrm{AUC}=0.66 \mathrm{p}=0.04$. VITRO score can predict the presence of varices with sensitivity of $69.5 \%$ and specificity of $50 \%$ at a cut off value $1.5 \mathrm{AUC}=0.065$ $\mathrm{P}=0.05$.

Conclusion: VWF and VITRO score rise significantly in patients with esophageal varices. Both markers can be reliable in prediction of the presence of EV's. VWF $\mathrm{Ag}$ can be reliable marker in prediction of risky and bleeding varices.

esophageal varices at a yearly incidence of $8 \%$. The yearly incidence of variceal hemorrhage is $5 \%-15 \%$. The most important risk factor for hemorrhage is the size of varices. The six week mortality after an episode of variceal bleeding is $20 \%$. This mortality is still considered high in spite of the improvement of the endoscopic management strategies [4]. The Baveno VI consensus recommended the use of non-invasive markers to rule out the presence of esophageal varices, in order to help 
minimize the number of unnecessary endoscopies and confine endoscopy to patients who are at high risk of variceal bleeding [5].

Von Willbrand factor is a coagulation factor secreted from the endothelial cells and it plays a role in both intrinsic and extrinsic pathways of coagulation [6]. The VITRO score is calculated by dividing the VWF $\mathrm{Ag}$ concentration on the platelet count it was first introduced by Maieron et al. together with VWF Ag, and among other well-known markers as a non- invasive predictor of cirrhosis [7]. They were also found to correlates well with liver function and hepatic venous pressure gradient and independently predicts clinical outcome [8].

\section{Aim of the work:}

To study the role of Von Willebrand Factor (VWF-Ag) and VITRO score in the prediction of presence of Esophageal Varices and occurrence of variceal bleeding in cirrhotic patients.

\section{PATIENTS AND METHODS}

Our study was a prospective analytical crosssectional study. Sample size was calculated according to expected positive predictive value of 70 , power of the study $85 \%$ and $95 \%$ confidence interval, population size is 1500 / year using EPI info 6.

It included 77 patients with liver cirrhosis and portal hypertension diagnosed by combination of clinical, radiological and laboratory evidence. They were randomly selected from patients admitted to tropical medicine endoscopy unit for upper GI endoscopy for the first time for diagnostic upper GI endoscopy either screening for esophageal varices or part of investigations of microcytic hypochromic anaemia or therapeutic upper GI endoscopy after an episode of upper GI bleeding. The following patients were excluded from the study; patients $<18$ years old, patients who didn't give consent to participate in the study, patients with known congenital or acquired coagulation defect due to a cause other than liver disease, patients on antiplatelet or anticoagulant therapy, patients with conditions that can lead to increased VWF Ag level such a pregnancy, sepsis, hyperlipidemia, cardiac or renal failure and finally, patients with intra or extrahepatic malignancy detected by history, clinical examination, basic radiological and laboratory evaluation.

On admission, patient underwent basic evaluation including thorough history taking and clinical examination. Patients also performed abdominal ultrasonography examination.

Portal hypertension was diagnosed based on sonographic evaluation of portal vasculature dilated portal vein, presence of collaterals around gall bladder bed or spleen hilum, the abolished changes in portal vein diameter with respiration, enlarged superior mesenteric and splenic veins and/orincresed spleen long axis $>12 \mathrm{~cm}$ [9].

Patients were subjected to routine laboratory investigations including; complete blood count and ESR, liver function tests namely serum albumin, bilirubin and serum transaminases, coagulation profile and kidney function tests namely serum BUN and serum creatinine. The severity of liver disease was classified according to Child-Pugh classification [10].

All patients underwent upper GI endoscopy evaluation by the same experienced endoscopist. Varices were graded into 4 grades according to Paquet grading [11]; Grade I: Small varices located in distal oesophagus or oesophago-gastric junction and disappear with insufflations, Grade II: One or two small varices located in the distal oesophagus, not disappearing with insufflations, Grade III: One or two small varices located in the distal oesophagus, not disappearing with insufflations, Grade IV: Varices are large, tortuous, or grape-liked shape, occupying more than $1 / 3$ of the esophageal lumen.

Portal hypertensive gastropathy was also classified according to Pungpapong et al. [12]; PHG grade $\mathrm{I}$ : mild reddening and congestive mucosa, no mosaic like pattern, PHG grade II: Severe redness and a fine reticular pattern separating the areas of raised edematous mucosa (mosaic like pattern) or fine speckling, PHG grade III: Point bleeding + grade II.

Patients were allocated into two groups according to the presence or absence of esophageal varices in endoscopic evaluation as follows; group I: included patients with esophageal varices (no= 59), 37 males and 22 females, 44 patients were admitted with beeding varices and group II: included patients with no esophageal varices $($ no=18), 7 males and 11 females.

Patients VWF level was measured using VIDAS ${ }^{\circledR}$ vWF which is a rapid ELFA (enzyme linked immunofluorescence assay test) for the quantitative measurement of von Willebrand factor. It runs on the automated VIDAS ${ }^{\circledR}$ immunoanalyzers (VIDAS, Biomerieux, france). 
VITRO score was calculated by dividing the VWF Ag concentration on platelet count [7].

\section{Statistical method}

The data were processed using SPSS program version 20 the categorical data were represented as number and percentage while the numerical data were represented as mean and standard deviation. The comparison between categorical data was done using chi square test and Fisher exact while comparison of numerical data was done using simple $t$ test for normally distributed data and Mann Whitney test for data that were not normally distributed. For comparison between multiple variants ANOVA test was used for normally distributed data but Kruskal Wallis test was used when data was not normally distributed. The univariate analysis of correlation used the Spearman correlation, while the multivariate analysis used multivariate regression model. Receiver operator characteristics curve was used to evaluate the clinical performance of VWF and VITRO score.

\section{RESULTS}

Table 1 summarizes the demographic, clinical, sonographic data of the patients. It shows that there were no significant differences between the studied groups as regards any of the demographic or clinical data. It represents also that the Child score show no statistically significant differences between the studied groups $(8.5 \pm 2.4$ in group I vs $9.9 \pm 3$ points in group II MW= $1.8 \mathrm{p}=0.06$ ). The comparison according to child grade showed no significant differences as regard the distribution of grades A, B and C in each group $(23.7 \%$, $44.1 \%$ and $32.2 \%$ successively in group I and $33.3 \%, 55.6 \%$ and $11.1 \%$ successively in group II $\mathrm{p}=0.2$ )

Table 1 also shows comparison between the studied groups as regards portal vein diameter and spleen long axis as measured by sonographic examination of the patients. It shows that portal vein diameter not significantly higher among patients with varices (group I) (1.6 \pm 0.28 vs $1.5 \pm$ $0.24 \mathrm{~cm} \mathrm{p}=0.17$ ). It also shows that the spleen long axis is significantly higher among patients in group I $(17.6 \pm 1.6$ vs $15.1 \pm 5.8 \mathrm{~cm} \mathrm{p}=0.001)$, although clinically the size of the spleen showed no significant difference between the groups.

Table 2 represents a comparison between the studied groups as regards routine laboratory parameters as well as VWF Ag level and VITRO score. The table shows there were no significant differences between the studied groups as regards any of the laboratory parameters. However, VWF $\mathrm{Ag}$ and Vitro score were significantly higher in the varices group (group I). VWF Ag level was $169.3 \pm 20.2$ in group I vs $146.8 \pm 35.5 \mu \mathrm{g} / \mathrm{dL}$ in group II $\mathrm{p}<0.001$. VITRO score was $2.2 \pm 1.1$ in group I vs $1.6 \pm 0.7 \mu \mathrm{g} / 10^{8}$ platelet $\mathrm{p}=0.05$.

Table 3 shows the association between the VWF Ag level and VITRO score and different varices, PHG and Child's grades, to demonstrate the association between the two markers and the severity of portal hypertension and liver disease. It shows that the VWF was significantly higher among patients with grades of varices. VWF Ag was significantly higher in patients with grade II and grades III and IV varices than in patients with grade 0 and grade I varices (174.2 \pm 8.2 in grade II and $174.1 \pm 19.8 \mathrm{IU} / \mathrm{dl}$ in grade III and IV vs $146.8 \pm 35.5 \mathrm{IU} / \mathrm{dl}$ in grade 0 and in grade I $\mathrm{p}=0.02$ ). VITRO score was also significantly higher in high varices grades $(3.2 \pm 1$.3in grade II and $3.3 \pm 0.0$ in grade III and IV vs $1.6 \pm 0.7$ in grade 0 and $1.8 \pm 0.6$ in grade $I \mathrm{p}<0.001$ ).

The presence of gastric varices caused no significant rise in the VWF $(171.7 \pm 12.6$ with gastric varices vs $162.6 \pm 27.8 \mathrm{IU} / \mathrm{dl}$ with no gastric varices $\mathrm{p}=0.4$ ). Meanwhile, VITRO score was significantly higher in patients with gastric varices $(2.3 \pm 0.5$ vs $2 \pm 1.2$ in patients without gastric varices $\mathrm{p}=0.04$ ). The presence of risky and bleeding varices was also associated with rise in both VWF Ag level and VITRO score (VWF Ag level was $178.9 \pm 10.3 \mathrm{n}=44$ vs 157.7 $\pm 28.3 \mathrm{n}=15$ in non-bleeding varices $\mathrm{MW}=0.8$ $\mathrm{p}<0.001$ ) (VITRO score was $2.5 \pm 1.0$ in bleeding varices $n=44$ vs $1.9 \pm 1.0$ in non-bleeding varices $\mathrm{n}=15 \mathrm{p}<0.001)$.

Table 3 also shows that the VWF Ag level was significantly higher in patients with portal hypertensive gastropathy. However, the differences between the different grades of PHG was not significant the values were as follows $157.5 \pm$ 25.7 in grade 0 and $184.6 \pm 13.5$ in grade I, 167.4 \pm 20.2 in grade II and $145.0 \pm 47.5$ in grade III. The association between VITRO score and PHG was more obvious. The VITRO score seems to be more related to the grade of PHG than VWF $\mathrm{Ag}$ level. The values were as follows $1.7 \pm 0.7$ in grade $0,2.1 \pm 0.8$ in grade I, $2.0 \pm 1.2$ in grade II and the highest value $2.6 \pm 0.5$ in grade III $\mathrm{p}=0.03$.

Table 3 also represents the association between VWF Ag and VITRO score Child grade of 
patients included in the study. About VWF Ag, the comparison of its level in different grades of hepatic decompensation revealed no significant rise with the deterioration of liver functions. The values were as follows; $160 \pm 25.5$ in Child A, 165.5 \pm 25.9 in Child B and 165.2 \pm 27.5 in Child $\mathrm{C} \mathrm{p}=0.3$. On the other hand, VITRO score showed a stronger association with the deterioration of liver functions, its values were as follows $1.4 \pm$ 0.7 in Child A, $2.6 \pm 1.2$ in Child B and finally $1.9 \pm 0.7 \mathrm{p}<0.001$. The lower mean in Child $\mathrm{C}$ may be because the mean of the sample is not representative of the data because it was not normally distributed.

\section{Univariate and multivariate analysis:}

Table 4 represents the correlation between VWF and VITRO score with the different variables in the study. It shows that there is a positive correlation between VWF and patient's age $(0.47 \mathrm{p}<0.001)$, creatinine $(0.34 \mathrm{p}=0.004)$, and esophageal varices grade $(0.42 \mathrm{p}<0.001)$. There was also a significant negative correlation to hemoglobin $(-0.23 \mathrm{p}=$ $0.04)$ and to bilirubin $(-0.26 \mathrm{p}=0.02)$. The VITRO score was correlated to all of the above mentioned except bilirubin. It showed also a significant correlation to the spleen long axis $(0.42 \mathrm{p}<0.001)$ and to the platelet count $(-0.68$ $\mathrm{p}<0.001$ ). Both scores revealed no statistically significant correlation to the PHG or to Child's score.

Table 5 represents the multivariate logistic regression model. That shows that despite all these variables that were shown to be related to VWF Ag level. After removing the role of possible confounders, VWF was the only independent predictor of the varices grade in this study. The following variables were excluded from the equation; Splenic long axis, portal vein diameter, PT and vitro score.

\section{ROC curve}

On blotting ROC curve for both VWF and VITRO score to test their performance in diagnosis of esophageal varices, large varices, bleeding varices,
PHG and severe PHG. It shows that both VWF and VITRO score had acceptable performance as predictors of EV. At cut off value of $153 \% \mathrm{VWF}$ can predict the presence of $\mathrm{EV}$ with sensitivity $88.1 \%$ and specificity of $61.1 \%$ and $\mathrm{AUC}=0.66$ $\mathrm{p}=0.04$. VITRO score can predict the presence of varices with sensitivity of $69.5 \%$ and specificity of $50 \%$ At a cut off value $1.5 \mathrm{AUC}=0.065 \mathrm{P}=0.05$ (Table 6).

As for prediction of large varices, both markers seem to have minor role as non-invasive predictors. At cut off value of $175.5 \%$, VWF can predict the presence of large EV with sensitivity and specificity of $57.9 \%$ and $69 \%$ successively $\mathrm{AUC}=0.6 \mathrm{p}=0.07$. VITRO score can predict large varices with sensitivity and specificity of $63.2 \%$ and $34.5 \%$ at a cut off value of $1.5 \mathrm{AUC}=0.55$ $\mathrm{p}=0.06$ (Table 6).

When we tested the two markers for prediction of risky and bleeding varices, VWF seem to have better performance than VITRO score as noninvasive predictor. At cut off value of $172.7 \%$, VWF can predict the presence of risky and bleeding varices EV with sensitivity and specificity of $61.4 \%$ and $62.7 \%$ successively AUC $=0.68 \mathrm{p}=0.008$. Whereas, VITRO score can predict risky and bleeding varices with sensitivity and specificity of $50 \%$ and $44.5 \%$ at a cut off value of 1.8 AUC $=0.48 \mathrm{p}=0.06$ (Table 6).

VWF is proved to be a better predictor of the presence of PHG, while VITRO score showed superiority in prediction of severe PHG. VWF predicted PHG at cut off value of $166.9 \%$ with sensitivity $73.6 \%$ and specificity of $66.7 \%$ AUC $0.65 \mathrm{p}=0.03$. VITRO score predicted PHG at cut off value of 1.8 with sensitivity $67.9 \%$ and specificity of $66.7 \%$ AUC $0.64 \mathrm{p}=0.06$. VWF predicted severe PHG at cut off value of $174.2 \%$ with sensitivity $50 \%$ and specificity of $60.3 \%$ AUC $0.48 \mathrm{p}=0.6$. VITRO score predicted PHG at cut off value of 1.8 with sensitivity $85.7 \%$ and specificity of $63.5 \%$ AUC $0.74 \mathrm{p}=0.005$ (Table $6)$. 
Table (1): Comparison between the studied groups as regards demographic, clinical and radiological characteristics

\begin{tabular}{|c|c|c|c|c|}
\hline Variables & $\underset{(n=59)}{\operatorname{Group} I}$ & $\begin{array}{c}\text { Group II } \\
(n=18)\end{array}$ & Test & $\mathbf{P}$ \\
\hline $\begin{array}{l}\text { Age (years): } \\
\text { Mean } \pm S D\end{array}$ & $56.5 \pm 10.6$ & $55.5 \pm 12.3$ & $\begin{array}{c}\mathrm{T} \\
0.33\end{array}$ & $\begin{array}{l}0.7 \\
\text { NS }\end{array}$ \\
\hline $\begin{array}{l}\text { Sex: } \\
\text { Males } \\
\text { Females }\end{array}$ & $\begin{array}{l}37(62.7 \%) \\
22(37.3 \%) \\
\end{array}$ & $\begin{array}{l}7(38.9 \%) \\
11(61.1 \%) \\
\end{array}$ & $\begin{array}{l}\mathrm{X}^{2} \\
3.2\end{array}$ & $\begin{array}{l}0.07 \\
\mathrm{NS}\end{array}$ \\
\hline $\begin{array}{l}\text { Residence: } \\
\text { Urban } \\
\text { Rural }\end{array}$ & $\begin{array}{l}18(30.5 \%) \\
41(69.5 \%)\end{array}$ & $\begin{array}{c}2(11.1 \%) \\
16(88.9 \%)\end{array}$ & $\begin{array}{l}\mathrm{X}^{2} \\
2.7\end{array}$ & $\begin{array}{l}0.1 \\
\text { NS }\end{array}$ \\
\hline $\begin{array}{l}\text { Smoking: } \\
\text { Smoker }\end{array}$ & $23(39.0 \%)$ & $5(27.8 \%)$ & $\begin{array}{l}X^{2} \\
0.7\end{array}$ & $\begin{array}{l}0.3 \\
\text { NS }\end{array}$ \\
\hline $\begin{array}{l}\text { Comorbidities: } \\
\text { Diabetes mellitus } \\
\text { Hypertension } \\
\text { No comorbidities }\end{array}$ & $\begin{array}{c}10(17.0 \%) \\
2(3.4 \%) \\
47(79.7 \%)\end{array}$ & $\begin{array}{c}0(0.0 \%) \\
2(11.1 \%) \\
16(88.9 \%)\end{array}$ & $\begin{array}{l}X^{2} \\
4.7\end{array}$ & $\begin{array}{l}0.09 \\
\text { NS }\end{array}$ \\
\hline History of bilharzias & $25(42.4 \%)$ & $9(50.0 \%)$ & Fisher & $0.8 \mathrm{NS}$ \\
\hline $\begin{array}{l}\text { Viral markers: } \\
H C V \\
H B V \\
\text { Both }\end{array}$ & $\begin{array}{c}53(89.8 \%) \\
2(3.4 \%) \\
2(3.4 \%)\end{array}$ & $\begin{array}{c}14(77.8 \%) \\
0(0.0 \%) \\
0(0.0 \%)\end{array}$ & $\begin{array}{l}\mathrm{X}^{2} \\
7.7\end{array}$ & $\begin{array}{l}0.052 \\
\text { NS }\end{array}$ \\
\hline Jaundice & $11(18.6 \%)$ & $7(38.9 \%)$ & $\mathrm{X}^{2} 3.2$ & $0.07 \mathrm{NS}$ \\
\hline Lower limb edema & $24(40.7 \%)$ & $5(27.7 \%)$ & $\mathrm{X}^{2} 0.5$ & $0.5 \mathrm{NS}$ \\
\hline $\begin{array}{l}\text { Ascites: } \\
\text { Non } \\
\text { Mild } \\
\text { Moderate } \\
\text { Tense } \\
\end{array}$ & $\begin{array}{l}21(35.6 \%) \\
10(16.9 \%) \\
12(20.3 \%) \\
16(27.1 \%) \\
\end{array}$ & $\begin{array}{l}4(22.2 \%) \\
4(22.2 \%) \\
5(27.7 \%) \\
5(27.7 \%)\end{array}$ & $\begin{array}{l}\mathrm{X}^{2} \\
1.3\end{array}$ & $\begin{array}{l}0.7 \\
\text { NS }\end{array}$ \\
\hline $\begin{array}{l}\text { Liver: } \\
\text { Shrunken } \\
\text { Average } \\
\text { Enlarged } \\
\end{array}$ & $\begin{array}{c}32(54.2 \%) \\
25(42.4 \%) \\
2(3.4 \%) \\
\end{array}$ & $\begin{array}{c}14(77.8 \%) \\
4(22.2 \%) \\
0(0.0 \%) \\
\end{array}$ & $\begin{array}{l}\mathrm{X}^{2} \\
3.3\end{array}$ & $\begin{array}{l}0.1 \\
\text { NS }\end{array}$ \\
\hline $\begin{array}{l}\text { Splenomegally } \\
\text { Mild } \\
\text { Moderate } \\
\text { Huge spleen }\end{array}$ & $\begin{array}{c}51(86.4 \%) \\
4(6.8 \%) \\
4(6.8 \%)\end{array}$ & $\begin{array}{c}14(77.8 \%) \\
2(11.1 \%) \\
2(11.1 \%)\end{array}$ & $\begin{array}{l}X^{2} \\
0.8\end{array}$ & $\begin{array}{l}0.6 \\
\text { NS }\end{array}$ \\
\hline $\begin{array}{l}\text { Encephalopathy } \\
\text { Non } \\
\text { Grade I } \\
\text { Grade II } \\
\text { Grade III } \\
\text { Grade IV }\end{array}$ & $\begin{array}{c}40(67.8 \%) \\
6(10.2 \%) \\
9(15.3 \%) \\
4(6.8 \%) \\
2(3.4 \%)\end{array}$ & $\begin{array}{c}8(44.4 \%) \\
3(16.7 \%) \\
3(16.7 \%) \\
2(11.1 \%) \\
0(0.0 \%)\end{array}$ & $\begin{array}{l}X^{2} \\
0.5\end{array}$ & $\begin{array}{l}0.5 \\
\mathrm{NS}\end{array}$ \\
\hline $\begin{array}{l}\text { Child's grade: } \\
A \\
B \\
C\end{array}$ & $\begin{array}{l}14(23.7 \%) \\
26(44.1 \%) \\
19(32.2 \%)\end{array}$ & $\begin{array}{c}6(33.3 \%) \\
10(55.6 \%) \\
2(11.1 \%)\end{array}$ & $\begin{array}{l}\mathrm{X}^{2} \\
3.1\end{array}$ & $\begin{array}{l}0.2 \\
\text { NS }\end{array}$ \\
\hline $\begin{array}{l}\text { Child's score: } \\
\text { Mean } \pm S D\end{array}$ & $8.5 \pm 2.4$ & $9.9 \pm 3.0$ & $\begin{array}{c}\mathrm{MW} \\
1.8\end{array}$ & $0.06(\mathrm{NS})$ \\
\hline $\begin{array}{l}\text { Portal vein diameter: } \\
\text { Mean } \pm S D\end{array}$ & $1.6 \pm 0.28$ & $1.5 \pm 0.24$ & $\begin{array}{c}\mathrm{T} \\
1.3\end{array}$ & $0.17(\mathrm{NS})$ \\
\hline $\begin{array}{l}\text { Spleen long axis: } \\
\text { Mean } \pm S D\end{array}$ & $17.9 \pm 1.6$ & $15.1 \pm 5.8$ & $\begin{array}{c}\mathrm{T} \\
3.3\end{array}$ & $\begin{array}{l}0.0012 \\
\mathrm{~S}\end{array}$ \\
\hline
\end{tabular}

NS: non-significant, S: significant, MW: mann-whitney 
Table (2): Comparison between the studied groups as regards the routine laboratory characteristics, VWF level, vitro score

\begin{tabular}{|c|c|c|c|c|}
\hline Variables & $\begin{array}{c}\text { Group I } \\
(\mathrm{n}=59)\end{array}$ & $\begin{array}{c}\text { Group II } \\
(n=18)\end{array}$ & Test & $\mathbf{P}$ \\
\hline $\begin{array}{l}\text { WBC's (x10'): } \\
\text { Mean } \pm S D\end{array}$ & $5.2 \pm 2.4$ & $5.0 \pm 2.7$ & MW & NS \\
\hline $\begin{array}{l}\text { Hemoglobin (g/dl): } \\
\text { Mean } \pm S D\end{array}$ & $9.2 \pm 1.5$ & $9.8 \pm 1.8$ & $\begin{array}{l}\mathrm{T} \\
1.4\end{array}$ & $\begin{array}{l}0.1 \\
\text { NS }\end{array}$ \\
\hline $\begin{array}{l}\text { Platelet count }(\mathbf{x 1 0}) \text { : } \\
\text { Mean } \pm S D\end{array}$ & $94.5 \pm 47.5$ & $134.5 \pm 113.5$ & $\begin{array}{c}\text { MW } \\
1.4\end{array}$ & $\begin{array}{l}0.1 \\
\text { NS }\end{array}$ \\
\hline $\begin{array}{l}\text { ESR }(\mathbf{m m} / \mathbf{m i n}): \\
\text { Mean } \pm S D\end{array}$ & $44.3 \pm 28.1$ & $41.2 \pm 17.0$ & $\begin{array}{l}\text { MW } \\
0.03\end{array}$ & $\begin{array}{l}0.9 \\
\text { NS }\end{array}$ \\
\hline $\begin{array}{l}\text { Total bilirubin }(\mathbf{m g} / \mathbf{d l}): \\
\text { Mean } \pm S D\end{array}$ & $1.9 \pm 2.0$ & $2.7 \pm 2.1$ & $\begin{array}{c}\text { MW } \\
0.8\end{array}$ & $\begin{array}{l}0.4 \\
\text { NS }\end{array}$ \\
\hline $\begin{array}{l}\text { Albumin (g/dl): } \\
\text { Mean } \pm S D\end{array}$ & $2.8 \pm 0.6$ & $3.0 \pm 1.2$ & $\begin{array}{c}\text { MW } \\
0.8\end{array}$ & $\begin{array}{l}0.4 \\
\text { NS }\end{array}$ \\
\hline $\begin{array}{l}\text { ALT (IU/L): } \\
\text { Mean } \pm S D\end{array}$ & $33.9 \pm 49.1$ & $20.4 \pm 8.1$ & $\begin{array}{c}\text { MW } \\
0.3\end{array}$ & $\begin{array}{l}0.7 \\
\text { NS }\end{array}$ \\
\hline $\begin{array}{l}\text { AST (IU/L): } \\
\text { Mean } \pm S D\end{array}$ & $50.1 \pm 43.2$ & $38.7 \pm 24.6$ & $\begin{array}{c}\mathrm{MW} \\
1.5\end{array}$ & $\begin{array}{l}0.1 \\
\text { NS }\end{array}$ \\
\hline $\begin{array}{l}\text { INR: } \\
\text { Mean } \pm S D\end{array}$ & $1.5 \pm 0.3$ & $1.3 \pm 0.2$ & $\begin{array}{l}\mathrm{T} \\
1.8\end{array}$ & $\begin{array}{l}0.07 \\
\text { NS }\end{array}$ \\
\hline $\begin{array}{l}\text { Creatinine: } \\
\text { Mean } \pm S D\end{array}$ & $1.0 \pm 0.4$ & $1.2 \pm 0.7$ & $\begin{array}{c}\mathrm{T} \\
1.7\end{array}$ & $\begin{array}{l}0.1 \\
\text { NS }\end{array}$ \\
\hline $\begin{array}{l}\mathbf{V W F}(\boldsymbol{\mu} \mathbf{g} / \mathbf{d L} \mathbf{L}) \\
\text { Mean } \pm S D\end{array}$ & $169.3 \pm 20.2$ & $146.8 \pm 35.5$ & $\begin{array}{c}\mathrm{T} \\
3.4 \\
\end{array}$ & $\begin{array}{c}<0.001 \\
\text { HS }\end{array}$ \\
\hline $\begin{array}{l}\text { Vitro score }\left(\boldsymbol{\mu g} / \mathbf{1 0}^{\mathbf{8}} \text { plt): }\right. \\
\text { Mean } \pm S D \\
\text { Median (range) }\end{array}$ & $\begin{array}{c}2.2 \pm 1.1 \\
1.9(1.4-3.0)\end{array}$ & $\begin{array}{c}1.6 \pm 0.7 \\
1.7(1.3-1.9)\end{array}$ & $\begin{array}{c}\text { MW } \\
1.9\end{array}$ & $\begin{array}{l}0.05 \\
S\end{array}$ \\
\hline
\end{tabular}

NS: non-significant; S: significant; HS: highly significant; MW: mann-whitney

Table (3): Association of VWF and Vitro score with Endoscopic findings and Child's grade in the studied patients

\begin{tabular}{|c|c|c|c|c|}
\hline Endoscopic findings & VWF & Test of sig. & $\begin{array}{l}\text { Vitro } \\
\text { score }\end{array}$ & Test of sig. \\
\hline $\begin{array}{l}\text { Esophageal varices grade: } \\
\text { No varices }(n=18) \\
\text { Grade } I(n=9) \\
\text { Grade II }(n=3) \\
\text { Grade } I I I, I V(n=19)\end{array}$ & $\begin{array}{r}146.8 \pm 35.5 \\
145.2 \pm 33.3 \\
* 174.2 \pm 8.2 \\
* 174.1 \pm 19.8\end{array}$ & $\begin{array}{c}\mathrm{KW} \\
11.1 \\
\mathrm{P}=0.02 \\
(\mathrm{~S})\end{array}$ & $\begin{array}{l}1.6 \pm 0.7 \\
1.8 \pm 0.6 \\
3.2 \pm 1.3 \\
* 3.3 \pm 0.0\end{array}$ & $\begin{array}{c}\text { KW } \\
17.6 \\
\mathrm{P}<0.001 \\
(\mathrm{HS})\end{array}$ \\
\hline $\begin{array}{l}\text { Gastric varices: } \\
\text { Present }(n=12) \\
\text { Absent } \\
\end{array}$ & $\begin{array}{l}171.7 \pm 12.6 \\
162.6 \pm 27.8 \\
\end{array}$ & $\begin{array}{c}\mathrm{MW}=0.8 \\
\mathrm{P}=0.4 \\
(\mathrm{NS})\end{array}$ & $\begin{array}{c}* 2.3 \pm 0.5 \\
2.0 \pm 1.2 \\
\end{array}$ & $\begin{array}{c}\text { MW } \\
2.0 \\
\mathrm{P}=0.04(\mathrm{~S}) \\
\end{array}$ \\
\hline $\begin{array}{l}\text { Risky signs and bleeding } \\
\text { varices: } \\
\text { Present }(n=44) \\
\text { Absent }\end{array}$ & $\begin{array}{c}* 178.9 \pm 10.3 \\
157.7 \pm 28.3\end{array}$ & $\begin{array}{c}\mathrm{MW}=0.8 \\
\mathrm{P}<0.001 \\
\quad(\mathrm{HS})\end{array}$ & $\begin{array}{c}* 2.5 \pm 1.0 \\
1.9 \pm 1.0\end{array}$ & $\begin{array}{c}\text { MW } \\
3.3 \\
\mathrm{P}<0.001 \\
(\mathrm{HS})\end{array}$ \\
\hline $\begin{array}{l}\text { PHG: } \\
\text { Normal }(n=23) \\
\text { Grade I }(n=9) \\
\text { Grade II }(n=31) \\
\text { Grade III }(n=14) \\
\end{array}$ & $\begin{array}{c}157.5 \pm 25.7 \\
* 184.6 \pm 13.5 \\
167.4 \pm 20.2 \\
145.0 \pm 47.5 \\
\end{array}$ & $\begin{array}{c}\mathrm{KW} \\
9.9 \\
\mathrm{P}=0.04 \\
(\mathrm{~S}) \\
\end{array}$ & $\begin{array}{l}1.7 \pm 0.7 \\
2.1 \pm 0.8 \\
2.0 \pm 1.2 \\
* 2.6 \pm 0.5 \\
\end{array}$ & $\begin{array}{c}\mathrm{KW} \\
10.2 \\
\mathrm{P}=0.03(\mathrm{~S})\end{array}$ \\
\hline $\begin{array}{l}\text { Child's grade } \\
A(n=20) \\
B(n=36) \\
C(n=21) \\
\end{array}$ & $\begin{array}{c}160 \pm 25.5 \\
165.5 \pm 25.9 \\
165.2 \pm 27.5 \\
\end{array}$ & $\begin{array}{c}\mathrm{F}=0.3 \\
\mathrm{P}=0.3(\mathrm{NS})\end{array}$ & $\begin{array}{r}1.4 \pm 0.7 \\
* 2.6 \pm 1.2 \\
* 1.9 \pm 0.7 \\
\end{array}$ & $\begin{array}{c}\mathrm{KW}=23.5 \\
\mathrm{P}<\mathbf{0 . 0 0 1} \\
\text { (HS) }\end{array}$ \\
\hline
\end{tabular}

NS: non -significant; S: significant, HS: highly significant, KW: Kruskal Wallis, MW: mann- whitney

Abdel Maksoud et al., Afro-Egypt J Infect Endem Dis 2019; 9(2):139-149

https://aeji.journals.ekb.eg/

http://mis.zu.edu.eg/ajied/home.aspx 
Table (4): Correlation between VWF and Vitro score and other variables of the studied patients (univariate analysis)

\begin{tabular}{|l|c|c|c|c|}
\hline \multirow{2}{*}{ Variables } & \multicolumn{2}{c|}{ VWF } & \multicolumn{2}{c|}{ Vitro score } \\
\cline { 2 - 5 } & $\mathbf{R}$ & $\mathbf{P}$ & $\mathbf{R}$ & P \\
\hline Age & 0.47 & $<\mathbf{0 . 0 0 1}(\mathbf{H S})$ & 0.47 & $<\mathbf{0 . 0 0 1}(\mathbf{H S})$ \\
\hline Child's score & 0.14 & 0.2 & 0.02 & 0.8 \\
\hline Portal vein diameter & -0.07 & 0.5 & -0.14 & 0.2 \\
\hline Spleen long axis & 0.2 & 0.08 & 0.42 & $<\mathbf{0 . 0 0 1}(\mathbf{H S})$ \\
\hline WBC's & 0.14 & 0.2 & -0.04 & 0.7 \\
\hline Hemoglobin & -0.23 & $\mathbf{0 . 0 4}(\mathbf{S})$ & -0.23 & $\mathbf{0 . 0 4}(\mathbf{S})$ \\
\hline Platelet count & -0.13 & 0.2 & -0.68 & $<\mathbf{0 . 0 0 1}(\mathbf{H S})$ \\
\hline Total bilirubin & -0.26 & $\mathbf{0 . 0 2}(\mathbf{S})$ & -0.11 & 0.3 \\
\hline Albumin & -0.01 & 0.9 & -0.05 & 0.6 \\
\hline ALT & 0.15 & 0.1 & 0.20 & 0.07 \\
\hline AST & 0.12 & 0.2 & 0.17 & 0.1 \\
\hline INR & 0.12 & 0.2 & 0.06 & 0.6 \\
\hline Creatinine & 0.34 & $\mathbf{0 . 0 0 4}(\mathbf{S})$ & 0.32 & $\mathbf{0 . 0 0 4}(\mathbf{S})$ \\
\hline Esophageal varices grade & 0.42 & $<\mathbf{0 . 0 0 1}$ & 0.42 & $<\mathbf{0 . 0 0 1}$ \\
& & HS & & HS \\
\hline PHG grade & -0.04 & 0.7 & -0.04 & 0.7 \\
\hline
\end{tabular}

S: significant, HS: highly significant

Table (5): Binary logistic regression analysis of EV presence with independent variables

\begin{tabular}{|l|c|c|c|c|c|}
\hline \multicolumn{1}{|c|}{ Variables in equation } & B & SE & $\operatorname{Exp}(\mathbf{B})$ & Wald & Sig. \\
\hline WBCs & -0.5 & 0.19 & 0.59 & 7.5 & NS \\
\hline VWF & 0.03 & 0.01 & 1.2 & 3.8 & $\mathbf{0 . 0 5}(\mathbf{S})$ \\
\hline Presence of risky signs & -20.3 & 7113.5 & 0.99 & 0.0 & $0.99(\mathrm{NS})$ \\
\hline
\end{tabular}

Variables not in the Equation: Splenic long axis, portal vein diameter, PT and vitro score.

S: significant, NS: non-significant 
Table 6: The clinical performance of VWF and VITRO score as predictor of varices, large varices, risky varices and bleeding varices, $\mathrm{PHG}$ and severe PHG

\begin{tabular}{|c|c|c|c|c|c|c|c|}
\hline & Cut off value & $\begin{array}{c}\text { Sensitivity } \\
\%\end{array}$ & $\begin{array}{c}\text { Specificity } \\
\%\end{array}$ & $\begin{array}{c}\text { PPV } \\
\%\end{array}$ & $\begin{array}{c}\text { NPV } \\
\%\end{array}$ & $\mathbf{A U C}$ & $\mathbf{P}$ \\
\hline \multicolumn{8}{|c|}{ Presence of varices } \\
\hline VWF & $153.0 \%$ & 88.1 & 61.1 & 100 & 61.1 & 0.66 & $0.04(\mathrm{~S})$ \\
\hline VITRO & 1.5 & 69.5 & 50 & 82.3 & 33.3 & 0.65 & $0.05(\mathrm{~S})$ \\
\hline \multicolumn{8}{|c|}{ Presence of large varices } \\
\hline VWF & $175.5 \%$ & 57.9 & 69 & 37.9 & 83.3 & 0.6 & $0.07(\mathrm{NS})$ \\
\hline VITRO & 1.5 & 63.2 & 34.5 & 24 & 74.1 & 0.55 & $0.08(\mathrm{NS})$ \\
\hline \multicolumn{8}{|c|}{ Presence of risky and bleeding varices } \\
\hline VWF & $172.7 \%$ & 61.4 & 62.7 & 67.5 & 54.1 & 0.68 & $0.008(\mathrm{~S})$ \\
\hline VITRO & 1.8 & 50 & 44.5 & 55 & 40.5 & 0.48 & $0.06(\mathrm{NS})$ \\
\hline \multicolumn{8}{|c|}{ Presence of PHG } \\
\hline VWF & $166.9 \%$ & 73.6 & 66.7 & 83.0 & 53.3 & 0.65 & $0.03(\mathrm{~S})$ \\
\hline VITRO & 1.8 & 67.9 & 66.7 & 81.8 & 48.5 & 0.64 & $0.06(\mathrm{NS})$ \\
\hline \multicolumn{8}{|c|}{ Presence of severe PHG } \\
\hline VWF & $174.2 \%$ & 50 & 60.3 & 21.9 & 84.4 & 0.46 & $0.6(\mathrm{NS})$ \\
\hline VITRO & 1.8 & 85.7 & 63.5 & 34.3 & 95.2 & 0.74 & $0.005(\mathrm{~S})$ \\
\hline
\end{tabular}

S: significant, NS: non-significant

\section{DISCUSSION}

Von Willbrand factor and VITRO score were proved by previous literature to have a correlation to liver cirrhosis, liver functions, severity of liver disease and portal hypertension. We aimed in this study to discover their role as non-invasive predictors of esophageal varices and risk of variceal bleeding among patients with liver cirrhosis. To achieve our aim we included 77 patients in our study randomly selected from the patients with liver cirrhosis admitted for diagnostic or therapeutic endoscopic intervention for the first time. Some of those patients were admitted after an episode of variceal bleeding. None of our patients had previous intervention that included any manipulation of esophageal varices to avoid the resultant impact on our results that this manipulation can cause. The patients were allocated into two groups according to the presence or absence of esophageal varices.

Comparison between the studied groups as regards their demographic, clinical, Child score revealed no significant differences as regards any of these data. This comes in favor of abolishing the effects of possible confounding factors. However, comparison of the studied groups as regards spleen long axis revealed that it was significantly higher among patients with esophageal varices. These findings come in agreement with Agha et al. [13] who reported that larger mean spleen diameter was observed in patients with varices as compared to patients without varices (147 mm versus $109 \mathrm{~mm}, \mathrm{P}=0.0006$ ) [13]. This finding also agrees with Kedar et al. [14] who said that splenomegaly ( $>12 \mathrm{~cm}$ in longest axis) may be the only evidence of elevated portal pressures [14].

The portal vein diameter was insignificantly different between the studied groups this disagrees with La fortune et al. [15] who said that portal vein diameter is not related to the severity of portal hypertension or the size of varices. They also stated that with more severe portal hypertension the flow will be hepatofugal and the portal vein diameter will even decrease [15].

Among all the laboratory parameters of the patients, only VWF and VITRO score showed significant differences between the studied groups. They both were significantly higher among patients with esophageal varices. Comparison of VWF in both studied groups reveals that it was significantly higher among patients with esophageal varices. These results are supported by Ferlitsch et al. [16] who reported that vWF was significantly higher in patients with clinically significant portal hypertension, compared to patients without portal hypertension [16]. This also agrees with El-Toukhy and Issa [17]who said that VWF level was significantly higher in patients with esophageal varices [17]. 
In our study we found that the VITRO score was significantly higher among patients of group I than in group II. This agrees with Hassan et al. [18] and Ibrahim et al. [19] who said that the VITRO score was significantly higher in patients with varices $[18,19]$.

This study also shows that both VWF and VITRO score were significantly higher among patients with higher grades of varices grade II, III, IV and in risky and bleeding varices than in lower grades of varices. They were also significantly higher in patients with severe portal hypertensive gastropathy. This is consistent with the findings by Ibrahim et al. [19] who said that VWF and VITRO score are significantly higher in patients with bleeding varices [19]. This also comes in agreement with Ghweil et al. [20] who reported that VWF-Ag level was higher in patients with bleeding varices than those without bleeding [20].

In this study, VWF level was significantly higher among patients with PHG than in patient with PHG grade 0 . VWF was insignificantly different in the different grades of PHG, and this agree with $\mathrm{Wu}$ et al. [21] who reported that, linear correlations were observed between levels of $\mathrm{vWF}$ in liver tissues with portal hypertensive gastropathy and esophageal varices severity [21].

This study reveals that the level of VWF was non-significantly different in different Child's grades. this disagree with Yilmaz et al. [22] who reported that plasma VWF-Ag level increase in cirrhotic patients and this is more pronounced with higher stages of decompensation according to Child-Pugh score [22]. VITRO score rises significantly in Child's grades B and C than in grade $\mathrm{A}$. This comes in agreement with Maieron et al. [7] who said that the VITRO score can predict the degree of cirrhosis and hepatic decompensation [7]. This debate can be explained by what Reuken et al. [23] said in the study in 2015. He claimed that the increased VWF in cirrhosis was due to systemic inflammatory response and systemic infection that affect those patients, this will lead to microthrombi formation in the portal circulation leading to further increase in the resistance to portal flow and more increase in the portal pressure. The study by Reukin et al. considers elevation of the VWF as a cause rather than a result or a predictor of portal hypertension. In our study we excluded patients with any systematic inflammatory condition that may lead to elevation of VWF [23]. This may be the reason that the association between VWF and the hepatic decompensation was not clear in our study. On the other hand, VITRO score showed strong association with Child's grade.

Univariate analysis in our study revealed that the VWF was significantly correlated to age, hemoglobin concentration, bilirubin, creatinine as well as esophageal varices. Wong et al. [24] and Poynard et al. [25] demonstrated that age was a major risk factor for subsequent fibrosis progression and further, that the rate of fibrosis progression accelerated with increasing age, this may be why age is correlated to VWF $[\mathbf{2 4 , 2 5 ]}$.

VITRO score was correlated to all those parameters along with spleen long axis and platelet count. In liver cirrhosis, variable degree of thrombocytopenia is present. Spleen long axis and platelet count are significantly correlated to the severity of portal hypertension [26].

The multivariate analysis for possible confounding factors revealed that VWF was independently correlated to the esophageal varices and that none of these variables correlated to the VWF confounded its relation to the esophageal varices. This comes in agreement with Ibrahim et al.[19] who found that VWF is an independent predictor of variceal bleeding [19].

Our study revealed that VWF can be useful as a predictor of EV at a cut off value of $153 \%$. It can also predict the presence of risky and bleeding varices at cut off value of 172.7. The previous literature gives variable results about this topic the cut off value ranged from $141 \%$ to $240 \%$, the sensitivity ranges from $75 \%$ to over $90 \%$ and the specificity ranged from $76 \%$ to $100 \%[\mathbf{1 5 , 1 6 , 1 7}$, $19,20,26]$. In our study, VITRO score performance as predictor of EV was also acceptable, but as predictor of bleeding the performance was not enough to be considered reliable. This disagrees with Hassan et al. [18] who said that the performance of VITRO score was superior to VWF Ag level as predictor of large and bleeding EV [18].

\section{CONCLUSION}

VWF and VITRO score are independently correlated to the presence and grade of esophageal varices. Both markers were proved to be useful as predictors of the presence of EV. VWF factor can also help in prediction of the presence of risky and bleeding varices. 
Ethical considerations: the design was approved by the IRB of faculty of medicine, Zagazig University

Fund: none

Conflict of interest: none

\section{REFERENCES}

1. Moller S, Bendtsen F: The pathophysiology of arterial vasodilatation and hyperdynamic circulation in cirrhosis. Liver Int. 2018; 38(4): 570-80.

2. Thabut D, Moreau R, Lebrec D: Non-invasive assessment of portal hypertension in patients with cirrhosis. Hepatology, 2011;53:683-694

3. Merli M, Nicolini G, Angeloni S, Rinaldi V, De Santis A, Merkel C, et al: Incidence and natural history of small esophageal varices in cirrhotic patients. J Hepatol 2003; 38:266-72.

4. Garcia-Tsao G, Sanyal AJ, Grace ND, Carey W: Practice Guidelines Committee of the American Association for the Study of Liver Diseases Practice Parameters Committee of the American College of Gastroenterology. Prevention and management of gastroesophageal varices and variceal hemorrhage in cirrhosis. Hepatology, 2007; 46:922-938

5. De Franchis R, Baveno VI faculty: Expanding consensus in portal hypertension: report of the Baveno VI consensus workshop: Stratifying risk and individualising care for portal hypertension. J Hepatol 2015;63:743-52.

6. Sadler JE (1998). "Biochemistry and genetics of von Willebrand factor". Annual Review of Biochemistry. 67:395-424. doi:10.1146/annurev. biochem.67.1.395. PMID 9759493.

7. Maieron A, Salzl P, Peck-Radosavljevic M, Trauner M, Hametner S, Schofl R, et al: Von Willebrand Factor as a New Marker for Non-Invasive Assessment of Liver Fibrosis and Cirrhosis in Patients with Chronic Hepatitis C. Alimentary Pharmacology \& Therapeutics, 2014; 39,331338.

8. La Mura V, Reverter JC, Flores-Arroyo A, Raffa S, Reverter E, Seijo S, et al: Von Willebrand factor levels predict clinical outcome in patients with cirrhosis and portal hypertension. Gut 2011; 60:1133-8.

9. Al-Nakshabandi NA: The role of ultrasonography in portal hypertension. Saudi J Gastroentrol. 2006;12:1,11-7.

10. Child CG, Turcotte JG: Surgery and portal hypertension. The liver and portal hypertension. Philadelphia: Saunders, 1964.
11. Paquet K. Prophylactic endoscopic sclerosing treatment of the esophageal wall in varices - a prospective controlled randomized trial. Endoscopy, 1982,14(1), 4-5

12. Pungpapong S, Keaveny A, Raimondo M, Dickson R, Woodward T, Harnois D et al: Accuracy and interobserver agreement of small-caliber vs. Conventional esophagogastroduodenoscopy for evaluating esophageal varices. Endoscopy, 2007, 39 (08), 673-680.

13. Agha A, Abdulhadi MM, Marenco S, Bella A, AlSaudi D, El-Haddad A, et al: Use of the platelet count/spleen diameter ratio for the noninvasive diagnosis of esophageal varices in patients with schistosomiasis. Saudi J Gastroenterol 2011;17: 307-10.

14. Kedar RP, Merchant SA, Malde HH, Patel VH: Multiple reflective channels in the spleen: A sonographic sign of portal hypertension. Abdom Imaging 1994;19:453-8.

15. Lafortune M, Marleau D, Breton G, Viallet A, Lavoie P, Huet PM. Portal venous system measurements in portal hypertension. Radiology $1984 ; 151: 27-30$

16. Ferlitsch $M$, Reiberger $T$, Salzl $P$, Hoke $M$, Schwengerer B, Ulbrich $\mathrm{G}$, et al. et al: von Willebrand factor as new noninvasive predictor of portal hypertension, decompensation and mortality in patients with liver cirrhosis. Hepatology 2012;56 (04) :1439-1447

17. El Toukhy $\mathrm{N}$, Issa $\mathrm{H}$ : predictive and prognostic vale of Von Willbrand factor in patients with cirrhosis and esophageal varices. Afro-Egypt $J$ Infect Endem Dis, 2019; 9(1),67-73.

18. Hassan EA, Abd El-Rehim AS, Sayed ZA, Ashmawy AM, Kholef EFM, Sabry A et al: Noninvasive Fibrosis Scores as Prognostic Markers for Varices Needing Treatment in Advanced Compensated Liver Cirrhosis. Open Journal of Gastroenterology, 2017;7, 230-242.

19. Ibrahim EH, Marzouk SA, Zeida AE, Sameh A, Lashen SA, Tahera TM: Role of the von Willebrand factor and the VITRO score as predictors for variceal bleeding in patients with hepatitis C-related cirrhosis, European $J$ of Gastroenterology and Hepatology, 2018, vol(00).

20. Ghweil AA, Arafav UA, Khodeary A, Salem AN: Predictors of Bleeding from Esophageal Varices: The Role of Factor VII and Von Willebrand Factor (vWF). Open Journal of Gastroenterology, 2014, 4, 152-158. 
21. Wu H, Yan S, Wang G, Cui S, Zhang C, Zhu Q: von Willebrand factor as a novel noninvasive predictor of portal hypertension and esophageal varices in hepatitis B patients with cirrhosis. Scand J Gastroenterol, 2015; 50: 1160-1169.

22. Yilmaz VT, Dincer D, Avci AB, Cetinkaya R: Significant Association between Serum Levels of Von Willebrand Factor (vWF) Antigen with Stages of Cirrhosis. Eurasian J Med 2015; 47 : 21-5.

23. Reuken PA, Kussmann A, Kiehntopf M, Budde U, Stallmach A, Claus RA, et al: Imbalance of von Willebrand factor and its cleaving protease ADAMTS13 during systemic inflammation superimposed on advanced cirrhosis. Liver Int. 2015 Jan; 35(1):37-45.

24. Wong S, Caronia D, Wight CR, Palmer J, Petrik P, Britton et al: Importance of age in chronic hepatitis
C virus Infection. J Viral Hepat, 1997; 4, 255 264

25. Poynard V, Ratziu F, Charlotte Z, Goodman J, Mc Hutchinson J: Rates and risk factors of liver fibrosis progression in patients with chronic hepatitis c. J Hepatol, 34 (2001), 730-739

26. Sanyal AJ, Fontana RJ, Di Bisceglie AM, Everhart JE, Doherty MC, Everson GT, et al. The prevalence and risk factors associated with esophageal varices in subjects with hepatitis C and advanced fibrosis. Gastrointest Endosc, 2006; 64:855-864.

27. Mahmoud HS, Ghweil AA, Bazeed SE, Fayed HM, Meguid MMA: Reliability of Plasma Von Willebrand Factor Antigen in Prediction of Esophageal Varices in Patients with Liver Cirrhosis. Open Journal of Gastroenterology, 2015; 5, 49. 57. 